\title{
Telling (Dangerous) Stories: A Narrative Account of a Youth Coaches' Experience of an Unfounded Allegation of Child Abuse
}

Melanie Lang, PhD, Department of Sport and Physical Education, Edge Hill University, Ormskirk, UK

Sarah Pinder, MA, Department of Sport and Physical Education, Edge Hill University, Ormskirk, UK.

\begin{abstract}
This paper (re)tells the story of a sports coach who was accused of emotionally abuse of a child athlete and, following an investigation by his club, cleared of the allegation. Accounts of such allegations are rare and no research to date has explored coaches' lived experiences of this. Such stories are 'dangerous' (Douglas and Carless 2009) and remain largely unrecognized and undebated as they represent a challenge to the metanarrative of child protection. Using the stance of a 'storyteller' (Smith and Sparkes 2008a), the coach-participant's story is presented as a monologue crafted using his words and embellished with literary techniques. The story is purposefully largely left open for interpretation in an attempt to encourage readers to engage cognitively and emotionally. Telling such a 'dangerous' story aims to add to the narrative repertoires available to those working in this field and expand understandings of child protection in sport.
\end{abstract}

Keywords: unfounded allegations of abuse, emotional abuse, coaching, child protection, narrative 


\section{Sport and the meta-narrative of child protection}

Since the conviction of Olympic swimming coach Paul Hickson in 1995 for the rape and indecent assault of teenage swimmers under his care, multiple examples of child abuse in sport, including sexual, emotional and physical abuse, have surfaced in and beyond the United Kingdom (UK) (e.g. Alexander et al. 2011, Parent 2011, Stafford et al. 2013, Vertommen et al. 2015). To date, much of this research has focused on sexual abuse and exploitation, and has centred on the perspective of athlete survivors; other forms of maltreatment, including emotional abuse, and research that focuses on the experiences of those accused of abuse - the contexts for this paper - have largely being side-lined from critical debate. In England, as a consequence of growing recognition that abuse occurs in sport, in 2001 the Child Protection in Sport Unit (CPSU) - one of the few state-backed national agencies globally with responsibility for safeguarding and child protection in sport - was established 'to help sports organisations minimize the risk of child abuse during sporting activities' and 'build the capacity of sports to safeguard children and young people' (CPSU 2013). Practitioners and academics have broadly welcomed the extension of child welfare regulations into sport in acknowledgement of the specificity of this context (Brackenridge 2001, Hartill and Lang 2014, Hartill et al. 2014, Parent and El Hlimi 2013), and the CPSU's work has been praised for going beyond the confines of a traditional abuse-prevention focused child protection approach by incorporating requirements that 'managers and senior staff promote a culture that ensures children are listened to and respected as individuals' (CPSU 2007, p. 17; see Hartill and Lang 2015).

Such developments conform to the meta-narrative of child protection. As with other social issues, child protection is characterized by a single master narrative that 
purports to explain the field (Fraidin 2010). This defines the vocabulary and context through which child protection issues are understood, shaping policies and creating a 'one dimensional world, which often fails to take account of the experiences of the powerless, of outsiders, of those oppressed by the status quo' (Fraidin 2010, p. 8). Within the meta-narrative of child protection, children are constructed as helpless, innocent victims who, as a result of their inherent vulnerability, are at risk of abuse and so require protecting from the 'deviant', 'evil' 'monster of our age' (Jewkes and Wykes 2012, p. 935) - the child abuser. Indeed, child abuse is what Nelson (1986, p. 27) calls a valance issue - an issue that elicits 'a strong, fairly uniform emotional response and does not have an adversarial quality'; in other words, there is limited public support for child abuse or abusers and overwhelming support for developments in child protection. As a result, child abuse is understood as a 'horrible, criminal atrocity' that results in 'the horrible suffering of the child(ren) in question' (Aubrun and Grady 2003, p. 3) and those who support child protection developments are constructed as 'guardian[s] and saviour[s] of individual children and the community at large' (Fraidin 2010, p. 16).

\section{Challenges to the meta-narrative}

Of course, this meta-narrative represents only one dominant version of many possible accounts. While we certainly do not wish to suggest that child abuse is acceptable, this meta-narrative serves, particularly when the issue at hand is a valance issue, to silence other versions of the story. However, accounts have recently begun to emerge that challenge the meta-narrative of child protection, particularly constructions of children as 'helpless innocents' at risk of being abused and adults as 'dangerous' to children. For example, some scholars argue that concern about the risk of child abuse, bolstered by high-profile investigations of predominantly sexual abuse outside sport, such as those of 
Jimmy Savile ${ }^{1}$, Rolf Harris ${ }^{2}$ and others (see Gray and Watt 2013), has escalated in Western societies to the status of a 'moral panic'. One result, it is claimed, is that there is now an atmosphere of suspicion surrounding adult-child interactions with adults frequently being constructed as potential abusers (Piper 2014; Piper et al. 2012ab, 2013).

In sport, for example, research suggests that, in awareness of this new childsafety discourse, some coaches are changing their practice out of concern they could be accused of abuse (Lang 2010, 2015, Piper 2015, Piper et al. 2012a, 2013). Lang (2010, 2015), for example, found some swimming coaches positioned themselves as 'safe' by ensuring they were perpetually visible and by limiting their use of adult-child physical contact to avoid being accused of sexual or physical abuse. Similar reluctance to touch child athletes - and anger and resentment at this - has subsequently been identified among some coaches in other sports, including rugby, gymnastics, football and paddle sports (Piper 2015, Piper et al.2012a, 2013). In response to such accounts, it is worth noting that the limited research on this topic has tended to describe coaches' actions without theoretical explanation other than to point the finger of blame at 'restrictive' child protection regulations (Lang 2015 is a notable exception; cf. Lang 2015 and Piper et al. 2012a, 2013). In addition, many studies fail to consider that these coaches may be misinterpreting child protection regulations - there are, for example, no regulations that prohibit appropriate (adult) coach-(child) athlete touch (see CPSU 2015) - and/or that coaches' concerns may be prompted by anger or frustration at challenges to their traditional coaching practices, a reluctance to accept that children's welfare is now a legitimate part of their responsibility (see for example, Hartill and Lang 2014), or at what they perceive as 'interference' from outside agencies (see Gleaves and Lang, forthcoming). Child protection regulations in sport and the CPSU's role in this have 
also received criticism. Child protection regulations have been called 'restrictive' (Piper et al. 2013, p. 27) and blamed for rendering inter-generational relationships 'toxic' (Piper 2015, p. 176), while the CPSU has been accused of promoting child protection 'as a priority over the wider goals of sports organisations ... contribut[ing] strongly to a ratcheting-up of regulatory pressure, arguably to an unhelpful extent' (Piper and Garrett 2012, p. 2).

Although such arguments have been criticized for being overly simplistic, adultrather than child-focused and failing to acknowledge the impact of wider societal discourses, organizational change and the policy implementation process (see, Lang 2015), it is nevertheless the case that critiques of child protection developments in sport have increased in recent years (see Piper 2015, Piper and Garrett 2012) representing an unusual challenge to the valance issue of child abuse. Such accounts are instructive; adults' constructions of themselves as 'risky' subjects and, simultaneously, 'risky' objects challenge the meta-narrative of child protection in that they suggest children are not the only individuals who are vulnerable and require protection.

The story (re)told here of a coach who was accused and later cleared of emotionally abusive behaviour ${ }^{3}$ against a child represents another potential challenge to the meta-narrative of child protection. Giving voice to this coach's story is significant because discussions of unfounded allegations ${ }^{4}$ of abuse are rare in the academic or professional literature, and no research to date has explored adults' experiences of this within sport. In recognition that the act of storytelling is, in itself, a creative act 'in that we create the world around us as we name it' (Fraidin 2010, p. 4), the paper aims to offer an alternative to the meta-narrative of child protection with characters who are not 'cardboard cut-outs of caricatured villains and victims' (Fraidin 2010, p. 25). By voicing such a story we intend to make visible the experience of being accused and later 
cleared of abusive behaviour and in so doing, to paraphrase Smith and Sparkes (2009), to increase the narrative repertoires available to those working in this field and expand understandings of child protection in sport.

\section{Narrative inquiry within sport and exercise research}

Since the turn away from positivism in the social sciences, qualitative researchers have problematized how meaning is generated and, concomitantly, how we conduct and represent social research. Narrative inquiry has, over the past 20 years, emerged as a popular methodological response to this challenge to positivist and post positivist paradigms in and beyond sport and exercise research (Lieblich et al. 1998, Markula and Silk 2011). As Pinnegar and Danes (2007, p.4), note, '[n]arrative inquiry embraces narrative as both the method and the phenomena of study'. It comes in various genres - poetry, (ethno)drama, music, dance, visual - but the unifying benefit is the potential for eliciting and sharing understandings and experiences which can often be lost when using a more traditional approach.

Waldron et al. (2011), for example, use a narrative methodology to unpick the experiences of athletes who have been hazed or who have perpetrated hazing and produce composite stories of these experiences to comprehensively and evocatively encourage readers to make sense of hazing from multiple vantage points. Similarly, in uncovering the narratives that spinal cord injured (SCI) people draw on to motivate them to take up and maintain physical activity, Papathomas et al. (2015) offer an indepth and empathetic representation of the experiences of SCI people, drawing draw attention to the persuasive power of narrative and its ability to guide people to action.

Meanwhile Carless and Douglas (2008) used narrative inquiry to explore the personal stories of physically active men with mental illness, demonstrating how 
creating and distributing alternative stories to the dominant narrative is important to avoid narrative wreckage and can help in the positive (re)construction of identity. Similarly, in (re)telling the stories of two 'survivors' of boyhood sexual abuse in sport, Hartill (2015) notes the usefulness of stories to draw attention to the contextual and personal in their experiences, and highlights the potential change offered by exposure to a wide range of narrative resources. These and other articles (see Carless 2012, Douglas and Carless 2009a, Fasting and Sand 2015, Smith 2013a), offer accessible, vivid and emotionally compelling accounts of participants' subjective experiences that invoke connection and understanding by encouraging readers to reflect on their own lives and experiences through the lived experience of the characters.

We consider these and other benefits (see Smith and Sparkes 2009) useful for our own exploration into a coaches' experience of an unfounded allegation. The experience of being accused of abuse is highly subjective, complex and nuanced, and while unfounded allegations are mercifully rare (Trocmé and Bala 2005), they can also be catastrophic for those accused (Hoyle et al. 2016). We were primarily interested in gaining the in-depth subjective experiences of a coach who has been accused of abuse, what it was like to be in that situation, to live through and beyond it, how the coach made meaning of and from the experience. Like Woike (2008), we reasoned narrative inquiry was the most appropriate way of accessing this.

The benefits of narrative as a method of representing our coaches' story were also important to us. We were also aware that the creation of detailed personal stories can be useful in prompting the sociological imagination, linking the personal to the public (Mills 1970), since it allows readers to make sense of the coach's story from their own vantage point - whether they be a child protection professional, a sports coach or a parent. This, in effect, gives the text back to the reader, 'the "other", who finds in [the 
story] part of themselves and parts of others just like them' (Denzin 1997, p. 123) and 'open[s] up unknown worlds to different audiences' (Dowling 2012, p. 47).

Moreover, we recognize that accounts of those who have experienced an unfounded allegation of abuse are rare in the literature, and when they do exist they are often silenced as they conflict with the meta-narrative of child protection. Through our experiences as coaches and lecturers in sport and PE, respectively, we had both heard anecdotal stories of coaches and PE teachers or student-coach/teachers who had been accused of but denied abuse or poor practice and were aware that statistics on unfounded allegations mask the shame, despair, heartache and personal and financial consequences of such an experience. For those accused, such allegations result in what Brackenridge (2001, p. 207) calls 'ambiguous culpability', with those accused often continuing to carry a 'spoiled identity' (Sikes and Piper 2011, p. 299), even if the allegation is later disproved. Yet despite repeatedly hearing such stories, we could find few examples in the literature, and none in the sports literature. These stories are, in Frank's words (1995, p. 137), 'unrecognized'. Our decision to seek out and write about such stories was, then, overtly ethical - an attempt to make visible the experience of suffering an unfounded allegation of (emotional) abuse so as to promote reflection about such allegations and their place in child welfare in sport and encourage readers to consider the issue.

Smith (2013b, p. 136) argues that (re)telling of 'unrecognized' stories is important because storytelling is central to the creation and maintenance of identity and can therefore 'help people who have fallen out of the story of which they were part to find a new story of which they can be part'. This can, in turn, provide comfort and solidarity as, by expanding the range of narrative resources available beyond that permitted by the meta-narrative, those affected come to understand they are not alone in 
their experience (Smith 2013b). In this way, providing such alternatives by which people can story their lives can prevent narrative wreckage and contribute to the creation and maintenance of a positive sense of self (Frank 1995, Douglas and Carless 2009a, Smith and Sparkes 2005).

\section{The study}

The study was underpinned by a constructionist epistemology that understands knowledge as socially constructed, fluid and subjective (Crotty 1998). The purpose of the study was the examine coaches' experiences of being accused and later cleared of abuse in sport. Finding coaches who have experience of an unfounded allegation of abuse was challenging given the rarity of such allegations (Children, Families and Schools Select Committee Inquiry 2009). After gaining ethical approval for the study, the Lead Officer (LO) for safeguarding and child protection from one national governing body of sport (NGB) was recruited to facilitate the search. The LO, NGB and participants were afforded anonymity due to the sensitivity of the topic, and consequently, all identifying and non-essential details features are fictional.

The LO emailed a link to around 400 affiliated coaches to the anonymous online survey that was used to identify any coach who had experience of being accused of abuse. Coaches were asked to identify whether they had experience of being accused of abuse in a sports context, the outcome of this and, in an effort to obtain a first-person account of this event, to leave their details if they were willing to tell their story in a recorded interview. From this, one coach was identified and agreed to participate. The interview used open-ended questions to guide the discussion and probe for further details and lasted just over two hours. Topics covered included how the details of the allegation, how it was raised, the process of investigation, the impact of the allegation 
on the coach and his state of mind throughout, and the emotions and behaviours the event invoked, both at the time and in retrospective.

\section{Crafting the story}

The standpoint adopted is that of a storyteller (Smith and Sparkes 2008). Storytellers 'assume that a good story is itself analytical and theoretical' (Ellis 2004, p. 195).

Writing the story, therefore, became for us part of the analytic process; analysis and theory were illuminated within the writing and contained within the telling, rather than requiring separate consideration (Richardson 2000). Yet while storytellers may avoid weighing down their stories with overt theoretical explanations and interpretations, this is not to say narratives are devoid of theory. Rather, "storytellers choose to craft a story to show theory' through creating evocative, embodied and personal stories that encourage the reader 'to think and feel with the story being shown rather than about it' (Smith and Sparkes 2009, p. 282). In showing rather than telling the story storytellers can 'communicate results in compelling and emotionally vibrant ways' (Smith 2013, p. 135), moving the reader towards a deeper understanding of the topic.

The transcript was the starting point for this 'storied approach to narrative' (Denzin 1997, p. 234). Firstly, as we were primarily interested in the content of the coach's story, a thematic analysis was conducted whereby the transcript was read and re-read and narrative threads and themes within it highlighted. Through an iterative process, a story was then crafted by the first author that combined these, using the verbatim words from the coaches' interview and embellished using 'creative nonfiction' techniques (Sparkes and Smith 2014). 'Creative nonfiction' writing is 'nonfiction' in the sense that it represents actual research data - in this case the words as spoken by the coach-participant - but 'creative' in the sense that it uses literary techniques to 
(re)present data in a storied manner - in this case 'compressing' the coaches' words (Caulley 2008); rearranging sentences to create a more logical, sequential account; and falsifying some of the 'facts' by, for example, changing identifying features to safeguard anonymity. The use of the term 'creative nonfiction', then, should not be interpreted to mean the story and its contents are imaginary. On the contrary, creative nonfiction accounts are 'deeply committed to the truth' (Caulley 2008, p. 426). Rather, the term 'creative' here refers to the form of representation rather than the 'facts' of the story and also serves as an acknowledgement of the (co-)constructedness of all narratives (Watson 2011). The resulting story is a 'performance science text' (Denzin 1997, p. 99) - a hybrid of theatre and social science in which a dramatic story is crafted from social science data and 'a version of the truth as the researcher sees it' (Clough 2002, p. 18, emphasis in original) is (re)presented.

Using this genre enables a personal, in-depth and more emotional and empathetic representation of experience (Smith and Sparkes 2009), bringing 'the written product of social research closer to the richness and complexity of [the coach's] lived experience' (Bochner and Ellis 1998, p. 7). Our hope is that this approach opens up the story so that it may resonate with readers and encourage them to think about and contribute their own responses to the topic. In addition because of the accessibility of this form of writing, showing the story in this way can help expand its potential audience beyond academic circles and, therefore, widen the narrative resources available in this context (Frank 2000, Smith 2013). Finally given our point about the marginalization of the voices of those who have experienced an unfounded allegation of abuse in the (academic and professional) literature, we felt it important to foreground the coaches' voice in the story. As others have noted (Carless and Sparkes 2008, McMahon and Penney 2015), creative nonfiction, especially when presented in the form 
of a first-person monologue as is the case here, gives the intimacy of an eyewitness account (Caulley 2008) and is therefore a compelling way of achieving this.

Following member checking and redrafting, the story was edited to reduce its length and avoid repetitive descriptions of the coach's emotional state of mind before being shared with the participant to encourage reflexive engagement. Feedback from the participant was positive; he described the story as faithful to his own experiences and noted that the story was 'a good [way] for people to be able to read about other people's experiences, see what they did in challenging situations and see what some of the pitfalls can be'. He also suggested some word changes and reordering of the narrative that he felt more accurately reflected the chronology of his thought processes. This version of the story was then passed to three academics for comment on its cohesiveness and the extent to which they considered it 'authentic' and engaging, resulting in further minor changes, primarily to certain words for comprehension purposes.

\section{The (fictional) context}

Dave is a 30-something qualified coach with a decade's experience of coaching youth football. He had been coaching for 10 years when he was accused of emotionally abusive behaviour against a youth footballer at his club. At the time, Dave was not married and lived alone. The allegation occurred around eight years before Dave's interview took place, at a time when child protection was in relative infancy in sport. A formal complaint was made by the child's parents and investigated by the Club Welfare Officer, but the case was not reported to the police, social services or the national governing body ${ }^{5}$. As such, Dave's case represents an allegation that would not show up 
on 'official' statistics. What follows is a fictionalized account of Dave's story of being accused and later cleared of emotionally abusive behaviour against a child.

\section{Dave's story}

I coach junior football, under $11 \mathrm{~s}$ at the $\mathrm{mo}^{6}$; I've been with them since under 8s. We've got one child-Jack - who's the class clown in training. He's harmless, wouldn't do anyone any harm, didn't do anything that would jeopardize another person's physical safety or wellbeing, but a lot of the other kids were starting to get cheesed off with this lad constantly messing about and taking 10 minutes off an hourlong session just in terms of his antics really - failing to listen, dancing and messing about when he should've been paying attention. And by not listening, whatever activity we were doing he'd get wrong, so it'd grind to a halt. The lad's parents never used to come to training; they used to drop him off in the car park so if you needed to speak to them, it was almost impossible. I had a word with him on a number of occasions in a nice friendly way, not picking him out or laying the law down to him but thankfully touch wood - I did this with a gentleman who, at the time, was our club chair. In a nutshell, having spoken to this kid on a number of occasions about his antics, one day I said to him, 'Can you please make sure when you get home that your mum or dad contact me so I can have a talk with them.' By the time I got home, the phone was going and it was his mum. She started to catalogue the number of times Jack had come home from training and told her that I'd told him off, and said that I was always picking on him at training. She said that he was always being singled out for chastisement, that he was always being shouted at - and anyone who knows me will tell you that I never raise my voice when coaching. I feel that if I've got to do that then I'm doing something wrong, I shouldn't be doing it. And the mother literally ranted and raved at me down 
the phone for about 20 minutes. She was literally screaming and shouting at me. That was the first time I started to get alarm bells that there was some mud flying around, going to come my way, which hopefully wouldn't stick.

It was emotional abuse that I was accused of - not just one incident of what the parents might have seen as an unfair way of handling something Jack may have done, but rather they said I was repeatedly picking on him and singling him out. They said that it was just him who I picked on, and that it was because I couldn't control the group, that I couldn't coach! That gutted me that did 'coz I think I'm a decent coach. I mean one of my abiding memories, unfortunately, was getting a clip round the ear hole for basically failing to score when I was a kid. Literally a clip round the ear hole! Thankfully those dark days are long gone. Just in recent years, in the junior game I've seen a number of coaches retire because of the way they coach - they coach like they're talking to 20 -and 30-year-old men so it's all shout, shout, shout. Thankfully that ethos is changing and I think the game has improved dramatically. But I'm not like that at all. I'm a decent coach so any allegation was hurtful. As she ranted on, she said I hadn't heard the last of this, that they were going to take it further. It only dawned on me slowly what she was happening, what she was accusing me of. I couldn't believe it at first. Emotional abuse, me? I couldn't understand how she could think that of me.

I reported the matter straight away to our club welfare officer and she told me to write everything down in case anything went formal. It was helpful in terms of having a specific point of contact to go to because the welfare officer is a very experienced person in terms of football and in terms of junior football in particular. She was very good in terms of pointing me in the right direction of information and how to proceed. 
This was after training on a Wednesday evening and that period between then and next training on the Saturday morning was really a very uncomfortable period. It was at the forefront of my mind pretty much every day. I'd wake up in the night thinking about it. I couldn't sleep. I'd lie there, just thinking and rethinking everything. I knew ultimately that I was in the right, but there's always an element of, 'It's one person's word against another', and you start to doubt yourself. I started thinking immediately of how many sessions I'd done where it was just me coaching, where I was effectively the only adult present, where it was just my word against this kid. I mean how would I be able to prove that I hadn't done anything? And I couldn't speak to anyone about it. There'd been no formal complaint, nothing to answer, so I had to just carry on as normal and keep shtum ${ }^{7}$.

At training on the Saturday, the lad didn't come and there was no contact from mum or dad. If anything, that heightened the anxiety because I thought, 'Have they just done one and we're never going to see them again or hear from them again?, which was a shame because he was a good player and he clearly enjoyed the game, which is what it's all about. This went on for another week. We heard nothing. It was a week of torture - constantly thinking about it. My stomach was in knots, you know. I questioned myself, you know, did I do this? Did I do that? Could it have been misinterpreted? Do I know what I'm doing? I mean, really? It'd pop up in my head and I'd wonder whether I was going to get a phone call from the regional office or from the regional welfare officer saying they'd had a complaint letter come in. I think any contact would've been better than no contact to be honest. I was almost hoping they'd get in touch, even if it was with a formal complaint, rather than having nothing, because I just didn't know anything. Nothing! 
Then on the Sunday the parents turned up with the lad expecting him to play, which I thought was interesting because if you're making formal allegations about a coach abusing your child to suddenly turn up on Sunday for a game I thought was a bit bizarre, especially when they're not usually there - you never see them at training usually. So we didn't do anything different, we did what we normally do, the game went ahead as normal. I tried to be normal, to put it out of my mind, but it was hard. I made an effort to be extra nice, but my heads was in bits. I found it very hurtful, I was frightened. And I kept thinking of my coaching license. I was very mindful of having my coaching qualification suspended because it's my job, I could lose my job just because of one allegation!

It wasn't until the following Saturday that our chair got an email from the parents saying they weren't happy with the treatment that their son was receiving and making a formal complaint. They acknowledged the lad's behaviour wasn't always perfect but they believed there was a number of kids that misbehaved during training and that they felt he was being singled out. They basically said that I couldn't control the kids, that the quality of the coaching wasn't up to scratch, if the coaching was of an appropriate standard then nobody would mess about, which was infuriating because they'd added another level - not just in saying their son was being singled out for emotional abuse, but also saying that the coaching wasn't of the standard required. I thought, 'God my reputation will be in tatters now'. The chair phoned me immediately and said the obvious thing was that they'd need to be an investigation and that we'd need to get together and have a meeting with the parents, and my first thought was, 
'Thank God for that! We can speak about it, I can have my say and there will be witnesses there.'

I had to wait another week for the meeting, and at training while I was waiting I kept thinking everyone was watching me - the parents, other coaches. Word had got out by then. It's like they wanted to see if I had a guilty conscience, check for themselves that I was as innocent as I said. I can still to this day recall the level of anxiety the whole thing caused. Even the thought of it made me anxious, very very anxious. It did have a big impact on me. I lost sleep over it. I couldn't concentrate. My stoOmach was churning all the time. You start to question yourself, you start to review things, to ask yourself, 'Have I possibly been a bit too hard on him?' 'Have I singled him out?' even though you're 99 percent sure of yourself.... You start to question even the simplest of things. What if no-one believes me? It's my word against theirs. How will I prove I've done nothing wrong? I've been coaching for years, never had a problem. The kids like me. The parents like me. I do a good job. I was sure of it, well I thought I was. But what if they don't believe me? I knew I could lose everything. One of my other thoughts at the time was, 'Heaven forbid if this had been a far more serious allegation, say one of something sexual. How would I have coped with that?' It was really quite scary to think of it. I know if anything like that had happened to me, one of the first things that would've happened is that I'd have been suspended from work, for obvious reasons. I think some kind of allegation in a sexual sense that would be worse just because generally in society it's perceived as generally the worse [kind of abuse]. And because if somebody accused me on Sunday of physical abuse, there would be a shadow there and some people would say, 'Well there's no smoke without fire', but that would go through due process to see if anything needed to be done. But if on Sunday there was an 
allegation of inappropriate touching or something sexual like that, the second that hit I'd be suspended immediately, the jungle drums would start beating, and people would start talking. It was frightening just realising that more serious allegations could've been made, so I knew that it could've been worse but still found it hard to cope with.

At the meeting, the chair and the welfare officer, who was also a coach, explained that they'd investigated the allegations. They'd spoke to me and to the other coaches. They said [that] what coaches often do at training is mix it up-sometimes another coach may take over - and that both the coaches [who'd worked with Jack's group] said although they didn't know Jack by name initially, their opinion was that there was one child who caused an issue throughout the session-Jack. Mum had another little explosion at that, but dad didn't say a great deal. Basically the welfare officer agreed the allegation was unfounded and I had no case to answer. I just couldn't believe it. It was like a weight had been lifted from me. What a relief! I had tears in my eyes from all the pressure. They'd believed me! After all that-all that worrying, all that I'd been thinking about what could've happened, how bad it could've been - they'd believed me!

Later that week [Jack's] dad came to training with the lad, he basically came up to me and apologized on behalf of himself and his wife and said they'd spoken to their son and they guaranteed his behaviour would improve. Turned out they'd asked the kid who he hung around with and had spoken to some of the kids' parents [about Jack's behaviour], who had told them their son is the class clown. I've found out since that Jack's behaviour at school is extremely challenging as well. What I found strange from the parents' perspective was that apparently they were fully aware of his behaviour at 
school and how challenging he was and they were regular attendees at school, so they must have had an idea of what he's like at football, so I don't understand their motives or what they expected. I think it's just a case of lashing out, a reactionary response. Certainly I think there's only a really small percentage of kids who think, 'If I say this, I could get them into trouble.' I don't think society in generally has necessarily turned into the kind of thing you see on television drama, you know, kids thinking, 'Let's call ChildLine. Let's get them done'. You tend to find that if you did anything to possibly offend somebody who's maybe 18 plus, the chances are they'll just come out and tell you, or they'll go away and have a little sulk and you can tell from their behaviour that there's something wrong and you can go and discuss it, but they're highly unlikely to go away and make a formal allegation against you. It's almost like a game of Chinese whispers and the younger the child is, the more confusing the game of Chinese whispers can get because the child can go home and say one thing to a parent and how does that come out the other side? I think that's what happened in my case, and it could happen to anyone.

I was absolutely unconcerned [about being accused of abuse] until that allegation was made against me. I would say I was probably a bit naive in the way I looked at things, you know, 'Everybody's happy campers. We're all off to enjoy ourselves'. The experience has definitely changed the way I do things. I would probably describe it probably as doing everything, you know, looking over your shoulder, even right down to little things. In the technical sense, in terms of process and procedure, it's probably a positive thing, but in terms of me emotionally and mentally, I would say it's a very negative thing. It's aged me, and made me more cautious. I look at things very rationally: I would say the brain has a certain percentage of thought-let's say there's 
$100 \%$ of my brain power, and if 20\% of that is constantly looking over my shoulder, I'm only $80 \%$ coaching rather than $100 \%$ coaching. Take an instance from last weekend. I took the under 8s and one of the lads said to me, 'Could you put a plaster on my knee 'coz I fell over at school yesterday and I've got a graze'. I wouldn't stay behind with this lad in the changing room and put a plaster on his knee out of the first aid kit. I made him come outside in plain sight where everyone was warming up, and I did it in the dugout. Now a couple of years ago, before that allegation, I wouldn't of given it a second thought -I'd of stuck a plaster on his knee and said, 'There you go sunshine, off you go'. Now you just think, 'Oh no, I'd better not'. And sometimes in coaching some kids do need an arm around the shoulder, sometimes you've got to carry a kid off the pitch if they've got a leg injury and things like that, practical things, so it can be hard.

In many ways it's sad. It would be nice to think that my first thought when I got to the session on Saturday would be the session and how I'm doing that session, but it won't be. The welfare isn't a secondary thing, it's almost the primary thing. I say [to new coaches], whilst you're only doing this to develop and help children [and] to put something back into the sport, you've got to look after number one. Never be alone with a child out of sight or sound. These are all things that are in the [training] book, but they're very difficult practices to maintain. But I would urge all coaches to do it. You've got to do it. I think really it's just a case of being smart, of being a lot more switched on, and I hate to say it but you've got to have that looking-over-your-shoulder mentality, which is a shame in many ways. You have to be smart about these things. Never, ever assume. It's almost a survival instinct.

\section{Discussion and conclusion}


The story (re)told here offers a rare insight into the lived experience of a coach who has experienced an allegation of emotionally abusive behaviour against a child that was later found to be unfounded. It provides an alternative to the meta-narrative on the valance issue of child protection and, in doing so, turns this on its head, with the coach taking on the character of innocent victim usually assigned to the child. Telling such a story is not intended as either an attempt to generalize about the efficacy of child protection in sport or to challenge to the rights of children to be protected from abuse and exploitation. Rather, we believe that voicing the story of a coach who has experienced an unfounded allegation of abuse and being in support of child protection developments in sport are not mutually exclusive positions; both are safeguarding issues, and a better understanding of unfounded allegations is necessary if we are to prevent such occurrences and support the accused and the accuser.

However, we recognize such a story is, to use Douglas and Carless' (2009b) words 'dangerous'. Told from the perspective of one 'oppressed by the status quo' (Fraidin 2010, p. 8), this coach's story gives voice to a perspective that is usually silenced, which allows the complex and potentially uncomfortable ethical questions it raises about child protection practice to go unacknowledged or debated (Douglas and Carless 2009b). As such, this story represents a first tentative step towards broadening the narrative resources available to coaches and others working with children in and beyond sport so as to widen the vocabulary through which this issue can be understood and encourage debate about unfounded allegations of abuse among academics, child welfare advocates and sports practitioners.

For some, both within the academy and the media (for example Piper et al. 2012ab, 2013), the existence of any unfounded allegations is used to argue the child protection system in sport is flawed. We consider this to be a serious mis-judgement. 
Rather, unfounded allegations are evidence that the system of investigating allegations is operating effectively since no allegation of abuse can be considered unfounded until it has been investigated and proven as such; after all, the response of those accused of abuse is often (false) denial (Mildred 2003). Equally importantly, although unfounded allegations are often assumed to be made by individuals with malicious intent, they may occur for a variety of reasons, including misunderstandings or misinterpretations, as the coach suspected occurred in his case.

In addition, concern about unfounded allegations and, perhaps more worryingly, the increasing profile of such allegations and the mistaken widespread perception that there is a high incidence of such allegations (Trocmé and Bala 2005) is disproportionate to the reality. For example, despite such heightened concern, unfounded allegations remain extremely rare - one study of referrals to the Football Association over a 40month period found that of 132 allegations, only one, for physical abuse, was unfounded (Brackenridge et al.2005), an incidence rate of $0.02 \%$. Meanwhile, unproven cases are likely to be more common given the difficulties in investigating abuse and securing evidence that reaches the threshold for pursuing a criminal case (Jütte et al. 2013). In other words, significantly more children are likely to be abused and either not report this or see their perpetrator released without a conviction than adults are to experience an unfounded allegation of abuse.

The focus on unfounded allegations, then, twists the reality of child abuse and, in so doing, has the potential to raise an element of doubt about all allegations, even those that are investigated and upheld. Worryingly, it could also result in people failing to believe children who are brave enough to report an allegation of abuse. But it also diverts attention away the more prevalent issues of substantiated, unsubstantiated and non-reported cases of abuse. For this reason, critical discussion of unfounded 
allegations of abuse and of the increased profile and concern about such allegations is vital. However, researchers (and coaches and coach educators) must be careful not to (re)produce such constructions if we are to avoid exacerbating the current moral panic about child (sexual) abuse and instead encourage the development of positive touch. Future discussions of positive touch would benefit from considering the usefulness of this approach.

Equally, as others have argued (Hartill 2014), social scientists must be aware of both stories that conform to the meta-narrative and those that challenge it; we have a moral responsibility to give voice to 'unrecognized' stories (Frank 1995, p. 137) such as that (re)told here. Consequently, while the story of a coach accused and later cleared of abuse may not 'slot easily into the most accepted narratives' of child protection (Plummer 1995, p. 115), it is a story that needs to be told.

\section{Notes}

1. Sir Jimmy Savile was a British DJ, TV presenter, charity fundraiser and celebrity, and is now considered 'one of the UK's most prolific known sexual predators' (Gray and Watt 2013, p. 24). In 2012, the police launched an investigation into historic abuse by the star following the broadcast of a programme alleging sexual abuse and rape by Savile in the 1970s. Savile is suspected of offences against some 450 children and adults between 1955 and 2009. He died in 2011 so cannot be prosecuted.

2. Rolf Harris is an Australian-born artist, singer-songwriter and TV personality who settled in Britain in the 1950s and whose career spanned almost six decades. He was sentenced to five years and nine months in prison in 2014 at 
age 84 for 12 counts of indecent assaults carried out between 1968 and 1986 on females aged between eight and 19 (BBC News 2014).

3. The CPSU (2013b) defines emotional abuse as: 'the persistent emotional illtreatment of a child so as to cause severe and persistent adverse effects.'

4. Not all allegations that fail to result in a prosecution are false; a distinction must be made between unfounded allegations, which are those that are investigated and proven to be untrue or erroneous, and unproven allegations, where there is insufficient evidence following an investigation that the maltreatment occurred or did not occur.

5. There is no legal obligation for organizations to report suspicions or allegations of abuse to the police, social services or the NGB.

6. British slang for 'moment'.

7. British slang for 'keep quiet'.

\section{Acknowledgements}

The authors would like to thank the three anonymous reviewers for their insightful comments on an earlier draft of this paper. In addition, thanks are due to Paul Potrac, Laura Purdy and Alan Thomson for their helpful comments when we were drafting this paper.

\section{References}

Alexander, K., Stafford, A., and Lewis, R., 2011. The experiences of children participating in organized sport in the UK. Edinburgh: University of Edinburgh/ NSPCC. 
Aubrun, A., and Grady, J., 2003. How the news frames child maltreatment: Unintended consequences. Chicago: Prevent Child Abuse America.

Bochner, A., and Ellis, C., 1998. Series editors' preface. In: A. Banks, and S. Banks, eds. Fiction and social research: By ice or fire. Walnut Creek: Altamira, 7-8.

Brackenridge, C. H., 2001. Spoilsports: Understanding and preventing sexual exploitation in sport. London: Routledge.

Brackenridge, C. H., Bringer, J., and Bishopp, D., 2005. Managing cases of abuse in sport. Child Abuse Review, 14 (4), 259-274.

British Broadcasting Corporation (BBC) News, 14 July 2014. Rolf Harris jailed for five years and nine months [online]. Available from: http://www.bbc.co.uk/news/uk28163593 [Accessed 16 February 2015].

Carless, D., 2012. Negotiating sexuality and masculinity in school sport: An autoethnography. Sport, Education and Society, 17 (5), 607-625.

Carless, D., and Douglas, K., 2008. Narrative, identity and mental health: How men with serious mental illness re-story their lives through sport and exercise. Psychology of Sport and Exercise, 9, 576-794.

Carless, D., and Sparkes, A. C., 2008. The physical activity experiences of men with serious mental illness: Three short stories. Psychology of Sport and Exercise, 9 (2), 191-210.

Caulley, D. N., 2008. Making qualitative research reports less boring: The techniques of writing creative nonfiction. Qualitative Inquiry, 14 (30), 424-449.

Child Protection in Sport Unit, 2007. Standards for safeguarding and protecting children in sport. Leicester: Child Protection in Sport Unit. 
Child Protection in Sport Unit (CPSU), 2013. Child abuse in a sports setting [online]. Available from: https://thecpsu.org.uk/help-advice/introduction-tosafeguarding/child-abuse-in-a-sports-setting/ [Accessed 29 January 2015].

Child Protection in Sport Unit (CPSU), 2015. Physical contact and young people in sport [online]. Available from: https://thecpsu.org.uk/resourcelibrary/2013/physical-contact-and-young-people-in-sport/ [Accessed 29 April 2015].

Children, Families and Schools Select Committee Inquiry, 2009. Allegations against school staff. London: The Stationary Office.

Clough, P., 2002. Narratives and fictions in educational research. Buckingham: Open University Press.

Crotty, M. 1998. The foundations of social science research: Meaning and perspective in the research process. London: Sage.

Denzin, N. K., 1997. Interpretive ethnography: Ethnographic practices for the 21st century. Thousand Oaks, CA: Sage.

Douglas, K., and Carless, D., 2009a. Exploring taboo issues in professional sport through a fictional approach. Reflective Practice, 10 (3), 311-323.

Douglas, K., and Carless, D., 2009b. Abandoning the performance narrative: Two women's stories of transition from professional sport. Journal of Applied Sport Psychology, 21 (2), 213-230.

Dowling, F., 2012. A narrative approach to research in physical education, youth sport and health. In: F. Dowling, A. Flintoff, and H. Fitzgerald, eds. Equity and difference in Physical Education, youth sport and health: A narrative approach. Abingdon: Routledge, 37-59.

Ellis, C., 2004. The ethnographic I. Oxford: AltaMira Press. 
Fasting, K., and Sand, T. S., 2015. Narratives of sexual harassment experiences in sport. Qualitative Research in Sport, Exercise and Health, 7 (5), 573-588.

Fraidin, M. I. 2010. Stories told and untold: Confidentiality laws and the master narrative of child welfare. Maine Law Review, 63, 1-60.

Frank, A., 1995. The wounded storyteller. Chicago: Chicago University Press.

Gleaves, T., and Lang, M., forthcoming. Kicking 'no touch' discourses into touch: Athletes' parents' constructions of appropriate (adult) coach-(child) athlete physical contact. Journal of Sport and Social Issues.

Gray, D., and Watt, P., 2013. Giving victims a voice: Joint report into sexual allegations made against Jimmy Savile. London: Metropolitan Police Service/NSPCC.

Hartill, M., 2014. Exploring narratives of boyhood sexual subjection in sport. Sociology of Sport Journal, 31 (1), 23-43.

Hartill, M., and Lang, M., 2014. 'I know people think I'm a complete pain in the neck': An examination of the introduction of child protection and safeguarding in British sport from the perspective of national governing body safeguarding lead officers. Social Sciences, 3 (1), 1-22.

Jewkes, Y., and Wykes, M., 2012. Reconstructing the sexual abuse of children: 'Cyberpaeds', panic and power. Sexualities, 15 (8), 934-952.

Jütte, S., Bentley, H., Miller, P., and Jetha, N., 2013. How safe are our children? London: NSPCC.

Lang, M., 2010. Surveillance and conformity in competitive youth swimming. Sport, Education and Society, 15 (1), 19-37.

Lang, M., 2015. Touchy subject: A Foucauldian analysis of coaches' perceptions of adult-child touch in youth swimming. Sociology of Sport Journal, 32 (1), 4-21. 
Lang, M., and Hartill, M., eds., 2015. Safeguarding, child protection and abuse in sport: International perspectives in research, policy and practice. London: Routledge.

Lieblich, A., Tuval-Mashiach, R., and Zilber, T., 1998. Narrative research: Reading, analysis and interpretation. Newbury Park, CA.: Sage.

Markula, P., and Silk, M., 2011. Qualitative research for physical culture. Basingstoke: Palgrave Macmillan.

McMahon, J. A., and Penney, D., 2015. Sporting parents on the pool deck: Living out a sporting culture? Qualitative Research in Sport, Exercise and Health. 7 (2), $153-169$.

Mildred, J., 2003. Claims-makers in the child sexual abuse 'wars': Who are they and what do they want? Social Work, 48 (4), 492-504.

Mills, C. W., 1970. The sociological imagination. London: Oxford University Press.

Nelson, B. J., 1986. Making an issue of child abuse: Agenda setting for social problems. Chicago: University of Chicago Press.

Papathomas, A., Williams, T. I., and Smith, B., 2015. Understanding physical activity participation in spinal cord injured populations: Three narrative types for consideration. International Journal of Qualitative Studies on Health and WellBeing, 10, 1-12.

Parent, S., 2011. Disclosure of sexual abuse in sport organizations: A case study. Journal of Child Sexual Abuse, 20 (3), 322-337.

Parent, S., and El Hlimi, K. 2013. Athlete protection in Quebec's sport system: Assessments, problems and challenges. Journal of Sport and Social Issues, 37 (3), 284-296. 
Pinnegar, S., and Danes, J. G., 2007. Locating narrative inquiry historically: Thematics in the turn to narrative. In D. J. Clandinin, ed., Handbook of narrative inquiry: Mapping a methodology. Thousand Oaks, CA.: Sage, 3-34.

Lang, M., 2010. Surveillance and conformity in competitive youth swimming. Sport, Education and Society, 15 (1), 19-37.

Piper, H., 2015. Touch in sports coaching and physical education: Fear, risk and moral panic. London: Routledge.

Piper, H., and Garrett, D., 2012. Hands-off sports' coaching: The politics of touch. ESRC end of award report. Report No. RES-000-22-4156 [online]. Swindon: Economic and Social Research Council. Available from: http://www.esrc.ac.uk/my-esrc/grants/RES-000-22-4156/read [Accessed 20 January 2015].

Piper, H., Taylor, B., and Garrett, D., 2012. Sports coaching in a risk society: No touch, no trust! Sport, Education and Society, 17, 1-15.

Piper, H., Garratt, D., and Taylor, B., 2013. Child abuse, child protection, and defensive 'touch' in PE teaching and sports coaching. Sport, Education and Society, 18, $583-598$

Richardson, L., 1999. Feathers in our CAP. Journal of Contemporary Ethnography, 28 (6), 660-668.

Smith, B., 2013a. Disability, sport and men's narratives of health: A qualitative study. Health Psychology, 32 (1), 110-119.

Smith, B., 2013b. Sporting spinal cord injuries, social relations, and rehabilitation narratives: An ethnographic creative non-fiction of becoming disabled through sport. Sociology of Sport Journal, 30, 132-152. 
Smith, B., and Sparkes, A., 2005. Men, sport, spinal cord injury, and narratives of hope. Social Science and Medicine, 61, 1095-1105.

Smith, B., and Sparkes, A. C., 2008. Narrative and its potential contribution to disability studies. Disability and Society, 23 (1), 17-28.

Smith, B., and Sparkes, A. C., 2009. Narrative analysis and sport and exercise psychology: Understanding lives in diverse ways. Psychology of Sport and Exercise, 10, 279-288.

Sparkes, A. C., and Smith, B., 2014. Qualitative research methods in sport, exercise and health: From process to product. Abingdon: Routledge.

Stafford, A., Alexander, K., and Fry, D., 2013. Playing through pain: Children and young people's experiences of physical aggression and violence in sport. Child Abuse Review. 22 (4), 287-299.

Trocmé, N., and Bala, N., 2005. False allegations of abuse and neglect when parents separate. Child Abuse and Neglect, 29, 1333-1345.

Vertommen, T., Schipper-van Veldhoven, N., Wouters, K., Kampen, K. J., Brackenridge, C. H., Rhind, D. J. A., Neels, K., and Van Den Eede, F., 2016. Interpersonal violence against children in sport in the Netherlands and Belgium. Child Abuse and Neglect. 51, 223-236.

Waldron, J. J., Lynn, Q., and Krane, V., 2011. Duct tape, icy hot and paddles: Narratives of initiation onto US male sport teams. Sport, Education and Society, $16(1), 111-125$.

Watson, C., 2011. Staking a small claim for fictional narratives in social and educational research. Qualitative Research, 11 (4), 395-408. 